JMKSP (Jurnal Manajemen, Kepemimpinan, dan Supervisi Pendidikan)

Volume 7 Issue 1 (2022) Page 141-153

ISSN 2614-8021 (Online) 2548-7094 (Print)

\title{
Conflict Analysis and Work Environment on Employee Productivity at the PP-PA Office of South Sumatera Province
}

\author{
Reva Maria Valianti ${ }^{1}$, Syukri Hamzah ${ }^{2}$ \\ ${ }^{1}$ Universitas PGRI Palembang, ${ }^{2}$ Universitas Bengkulu
}

Corresponding Author E-mail: revavalianti@univpgri-palembang.ac.id

Received 3 October 2021; Revised 28 December 2021; Accepted 15 January 2022

\begin{abstract}
The purpose of this study is 1) to determine the effect of the work environment on the work productivity of employees at the PP-PA Office of South Sumatera Province, 2) to determine the effect of work conflict on employee work productivity in the PP-PA Office of South Sumatera Province. And 3) to determine the effect of the work environment and work conflict on employee work productivity at the PP-PA Office of South Sumatera Province. The research method used is a descriptive method with a research sample of 48 ASN employees at the PP-PA Office of South Sumatera Province. Data analysis by questionnaire. The results of the study with indicators of work conflict, work environment, and employee productivity showed a good predicate with a magnitude of $79.64 \%$. Our recommendation is to improve the work environment and prevent and handle work conflicts properly will increase employee productivity at the PP-PA Office of South Sumatera Province.
\end{abstract}

Keyword: Conflict, Environment, Work, Productivity, Employees

\section{Introduction}

The Office of Women's Empowerment and Child Protection or the PP-PA Office of South Sumatera Province is one of the agencies engaged in secretarial activities that organizes women's empowerment and child protection activities. With the Regulation of the Governor of South Sumatera Province Number 67 of 2016 concerning Organizational Structure, Description of Duties and Functions of 
the PP-PA Office of South Sumatera Province, the position of the PP-PA Service is the implementing element of government affairs under the authority of the provincial government in the field of Child Protection Human Resources.

Human resources (HR) are very important and cannot be separated from an organization, institution, or company. Human resources are the key that determines the development of the company. In essence, human resources are in the form of humans who are employed in an organization as movers, thinkers, and planners to achieve organizational goals.

Each agency has employees as human resources who carry out all forms of, operational activities. Employees in a supportive work environment can affect their productivity, so that employee productivity increases, an adequate work environment is needed, both physically and non-physically. The work environment in the PP-PA Office can be said to be quite physical and nonphysical, starting from the air temperature, physical lighting, supported, and supported by complete office equipment.

Various kinds of activities or activities carried out by employees will require them to always interact with co-workers both between employees, superiors, applicable regulations, and all forms of activities that result in an interaction. The interaction that occurs does not rule out the possibility for an employee to be involved in work situations between fellow employees and with superiors, this can reduce employee productivity at the time of implementation.

The results of previous research (Wardhana, E., Lengkong, V. 2019), human resources play a very important role in the operational success of a company and in supporting the development of a company or organization. Human plans are at the forefront and become the foundation for companies to be able to survive in today's era of globalization. The results showed that simultaneously the work environment, conflict, and communication affected the performance of TVRI Manado employees, while partially the work environment had no effect.

After that, based on research (Kambey, C., Adolfina, A., \& Sendow, G. 2021) the research shows the following: 1) Work conflict has a positive and significant effect on employee performance at the Regional Education Office of North Sulawesi Province; 2) Work Communication has a positive and significant effect on employee performance at the Education Office of North Sulawesi Province; 3) The work environment has a positive and significant effect on employee performance at the Education Office of North Sulawesi Province. 4. Work Conflict, Work Communication, and Work Environment are very strong 
and have a positive simultaneous effect on Employee Performance at the Education Office of North Sulawesi Province.

Then the results of research (Widyawati, ED 2020) Analysis of the Effect of Role Conflict, Work Environment and Work Stress on Employee Performance with Organizational Culture as an Intervening Variable. Other results show that there is no influence between the variables of role conflict, work environment, and work stress on organizational culture. Organizational culture variable cannot mediate the influence between role conflict variable and work stress variable. The work environment can be mediated by organizational culture on employee performance. Keywords: Role Conflict, Work Environment, Work Stress, Organizational Culture, Employee Performance. Furthermore, it was found by (Syarifudin, I. 2021) that the results of the study show that workload, work conflict, and the physical work environment are things that need to be considered to reduce employee work stress so that it becomes even better. For the realization of the ideals of UD Rahmat Kutowinangun.

This statement according to Kurbani (2018) in the implementation of achieving its goals, the most important factor is Human Resources, because an agency will not be able to run well without the role of Human Resources (employees) as a driving force for organizational life. Able to manage and run infrastructure in an agency. Meanwhile, according to (Sedarmayanti. 2018) the work environment is everything that is in the workplace, which can affect individuals directly or indirectly. Every employee will feel comfortable at work if they have a good work environment so that it can cause something positive in their work that can support the productivity of each individual itself. Productivity can also be achieved if an employee can adapt to his work environment.

Furthermore, according to (Darmayanti. 2017) the work environment is a place or space where employees carry out their routine activities as workers in an agency or company. This means that all forms of activities carried out by individuals cannot be separated from the work environment itself, so it can be said that between employees and their work environment is a single entity. Understanding the work environment above, it can be concluded that the work environment is everything that exists in the work environment, both physical and non-physical, which can affect employees in carrying out their duties so that it becomes one of the factors that influence it determine employee productivity.

Then according to (Sunyoto, 2012) conflict is a disagreement between two or more members of an organization or group within an organization that arises 
because they have to use scarce resources together or carry out activities together or because they have differences. Status, goals, values, and perceptions. (Kristanto, 2020) states that conflict is a dispute between employees that arises from differences in thought processes, attitudes, understandings, interests, and perceptions or differences of opinion.

Meanwhile, according to (Hasibuan Malayu, 2012) conflict is an unhealthy competition based on ambition in matters such as discrepancies, disputes, or tensions both within individuals and social entities such as individuals, groups, or organizations. Then according to (Hamali. 2018) states that conflict is a dispute regarding the needs, values, and ambitions of individuals or groups that are felt by members of an agency or company.

With the above understanding, it can be concluded that workplace conflict is defined as an imbalance or discrepancy that occurs between individuals or groups that can be caused by many things within a company or agency. For example, different perceptions about a job.

Work productivity according to (Sutrisno, 2019) is a measure of productive efficiency, the ratio between output and input results, input is limited by labor, for output is measured using physical units, forms, and values. Furthermore, according to (Lestari, ND, \& Toyib, M. 2017) as good citizens and care for the environment around us, we must be able to have creativity and high concern for the environment, starting from the environment in which we live, public places and natural surroundings. Damage to natural ecosystems is mostly carried out by human activities, especially damage due to garbage or waste that can pollute the water, soil, and air environment. From these problems, students must be able to take advantage of the best opportunities, utilizing environmental waste into creative products.

According to (Yusuf, 2015) productivity is an attitude that always has an effort to improve itself with the principle that today's view of life must be better than today. Yesterday and tomorrow must be better than today. This means that the individual must have motivation in himself to always improve performance in carrying out the tasks assigned to him. Based on the opinion of Masnunah, M., \& Lestari, ND (2020) utilization is an act of caring for oneself others, and the environment. Whereas the use of waste is a commendable act of a person where he can benefit others and the environment by utilizing waste into creative products that have economic value. So it can be concluded that employee productivity is the result of employee performance both individually and in groups within a 
certain time, to see performance results that can be used as a benchmark or reference for employee performance in previous years.

The problems raised in this study are too broad to be studied thoroughly because we are aware of the limitations of time, ability, and cost. So the authors need to define the problem clearly and focus so that the problem does not spread, the indicators used in the work environment variables are lighting/light in the workplace, temperature/air temperature at work, noise at work, air circulation in the workplace. Workplace, and safety at work. The indicators of work conflict used are different perceptions/views, excessive competition, different goals, interdependence, and personal character. The indicators used in the productivity variable are ability, increased results achieved, morale, self-development, and quality. We also examines employee productivity indicators which are specifically focused on government agency employees.

The problem that will be raised is the Conflict and Work Environment on Employee Productivity at the PP-PA Office of South Sumatera Province. The purpose of this study is, 1) to determine the effect of the work environment on the work productivity of employees at the PP-PA Office of South Sumatera Province. 2) To determine the effect of work conflict on employee work productivity at the PP-PA Office of South Sumatera Province. And 3) to determine the effect of the work environment and work conflict on employee work productivity at the PP-PA Office of South Sumatera Province.

\section{Methods}

The method used in this research is descriptive, which is carried out to assess the characteristics of data. The approach in this research is quantitative. This study is intended to test the hypothesis that has been proposed by finding the magnitude of the influence of the independent variable on the dependent variable, and the intervening variable. In this study, correlation analysis will be conducted between the independent variables (role conflict and work environment) with the dependent variable on employee productivity. In this descriptive analysis section, we describe the respondents and also related to the variables used in the study. This description will be explained through a table containing the percentage of Respondents answers to each question item in the questionnaire that has been given. The number of respondents in this study was 48 respondents, namely ASN employees at the PP-PA Office of South Sumatera Province, with a total of 30 questionnaires. 
Table 1. Variable Operational Definition

\begin{tabular}{|c|c|c|c|c|c|}
\hline No & Variable & Definition & Indicator & $\begin{array}{c}\text { Question } \\
\text { Items }\end{array}$ & Amount \\
\hline 1 & Work Conflict & $\begin{array}{l}\text { Work conflict is an } \\
\text { imbalance or } \\
\text { discrepancy that occurs } \\
\text { between individuals in } \\
\text { the PP-PA Office of } \\
\text { South Sumatera } \\
\text { Province. }\end{array}$ & $\begin{array}{l}\text { According to Kristanto } \\
\text { (2020:26) } \\
\text { Differences in } \\
\text { perception/views } \\
\text { Excessive competition } \\
\text { Different goals } \\
\text { Interdependence } \\
\text { Personal character }\end{array}$ & $\begin{array}{c}1-2 \\
\\
3-4 \\
5-6 \\
7-8 \\
9-10\end{array}$ & 10 \\
\hline 2 & $\begin{array}{l}\text { Work } \\
\text { Environment }\end{array}$ & $\begin{array}{l}\text { The work environment } \\
\text { is everything that is in } \\
\text { the work environment } \\
\text { of the PP-PA Office, } \\
\text { both physically and } \\
\text { non-physically. }\end{array}$ & $\begin{array}{l}\text { According to } \\
\text { Sedarmayanti } \\
(2018: 28) \\
\text { Lighting/lighting in the } \\
\text { workplace } \\
\text { Temperature/air } \\
\text { temperature in the } \\
\text { workplace } \\
\text { Noise at work } \\
\text { Air circulation in the } \\
\text { workplace } \\
\text { Safety at work }\end{array}$ & $\begin{array}{c}11-12 \\
13-14 \\
15-16 \\
17-18 \\
19-20 \\
\end{array}$ & 10 \\
\hline 3 & \begin{tabular}{|l|} 
Employee \\
Productivity
\end{tabular} & $\begin{array}{l}\text { Employee productivity } \\
\text { is the result of the } \\
\text { performance of the PP- } \\
\text { PA Office of South } \\
\text { Sumatera Province, } \\
\text { both individually and in } \\
\text { groups within a certain } \\
\text { period. }\end{array}$ & $\begin{array}{l}\text { According to Sutrisno } \\
\text { (2019:104-105) } \\
\text { Ability } \\
\text { Improve the results } \\
\text { achieved } \\
\text { Work spirit } \\
\text { Self-development } \\
\text { Quality }\end{array}$ & $\begin{array}{l}21-22 \\
23-24 \\
25-26 \\
27-28 \\
29-30\end{array}$ & 10 \\
\hline & & & & & 30 \\
\hline
\end{tabular}

In this study, we used a Likert scale measurement. According to (Sugiyono, 2019) the Likert scale is used to measure attitudes, opinions, and perceptions of a person or group of people about social phenomena. In research, this social phenomenon has been specifically defined by us, hereinafter referred to as the research variable. The answers to each instrument item using a Likert scale range from strongly agree to other. 
Here are the ranges in the Likert scale rating:

1. Strongly Agree (SA)

2. Agree (A)

3. Hesitating $(\mathrm{H})$

4. Disagree (D)

5. Strongly Disagree (SD)

Table 2. Likert Scale Measurement

\begin{tabular}{|c|c|c|c|c|c|}
\hline Statement & SA & A & H & D & SD \\
\hline Positive & 1 & 2 & 3 & 4 & 5 \\
\hline Negative & 5 & 4 & 3 & 2 & 1 \\
\hline
\end{tabular}

In this study, the questionnaire data analysis was calculated by the formula:

$$
\mathrm{P}=\mathrm{f} / \mathrm{n} \times 100 \% \text { (Sudijono, 2011, p. 48) }
$$

Description:

P: Percentage of students' learning difficulties in online learning

$f:$ Number of answers for each category

$\mathrm{n}$ : Total number of respondents in the largest category

Table 3. Category Percentage Questionnaire

\begin{tabular}{|c|c|}
\hline Intervals & Category \\
\hline $86-100$ & Very well \\
\hline $76-85$ & Good \\
\hline $60-75$ & Enough \\
\hline $55-59$ & Not Enough \\
\hline$\leq 55$ & Very Less \\
\hline
\end{tabular}

Source: (Purwanto, 2017)

\section{Results and Discussion}

The data used in this study is primary data. Primary data is data obtained directly from an object under study. The data collection process used a questionnaire distributed to 48 ASN employees at the PP-PA Office of South Sumatera Province. The questionnaire distributed consisted of questions given to all respondents who acted as research objects. We examine several components, namely Work Conflict, Work Environment, and Employee Productivity. Then we distribute the respondents' answers into the components they want to study. 
Table 4. Work Conflict Indicator

\begin{tabular}{|c|c|c|c|c|}
\hline No & Value & Frequency & $\mathbf{N}(\%)$ & Predicate \\
\hline 1 & $86-100$ & 21 & 43.75 & Very well \\
\hline 2 & $76-85$ & 12 & 25 & Good \\
\hline 3 & $60-75$ & 8 & 17 & Enough \\
\hline 4 & $55-59$ & 4 & 8 & Not Enough \\
\hline 5 & $\leq 55$ & 3 & 6.25 & Very Less \\
\hline \multirow{2}{*}{\multicolumn{3}{|c|}{ Average }} & 100 & \\
\hline & & & 81.06 & Good \\
\hline
\end{tabular}

The work conflict indicator table shows the largest percentage, namely in the Very Good predicate of $43.75 \%$ with a value of $86-100$. While the smallest is $6.25 \%$ with a Very Poor predicate at a value of 55 . With an average value of $81.06 \%$ in a Good predicate.

Table 5. Work Environment Indicator

\begin{tabular}{|c|c|c|c|c|}
\hline No & Value & Frequency & $\mathrm{N}(\%)$ & Predicate \\
\hline 1 & $86-100$ & 18 & 37.5 & Very well \\
\hline 2 & $76-85$ & 14 & 29.17 & Good \\
\hline 3 & $60-75$ & 9 & 18.75 & Enough \\
\hline 4 & $\begin{array}{l}55-59 \\
\end{array}$ & 5 & 10.41 & Not Enough \\
\hline 5 & $\leq 55$ & 2 & 4.17 & Very Less \\
\hline & Total & 48 & 100 & \\
\hline \multicolumn{3}{|c|}{ Average } & 78.76 & Good \\
\hline
\end{tabular}

The work environment indicator table shows the largest percentage, namely the Good predicate of $29.17 \%$ with a value of $76-85$. While the smallest is $4.17 \%$ with the predicate Very Poor at a value of 55. With an average value of $78.76 \%$ in the predicate Good.

Table 6. Employee Productivity

\begin{tabular}{|c|c|c|c|c|}
\hline No & Value & Frequency & $\mathrm{N}(\%)$ & Predicate \\
\hline 1 & $86-100$ & 20 & 41.67 & Very well \\
\hline 2 & $76-85$ & 12 & 25 & Good \\
\hline 3 & $60-75$ & 9 & 18.75 & Enough \\
\hline 4 & $55-59$ & 4 & 8.33 & Not Enough \\
\hline 5 & $\leq 55$ & 3 & 6.25 & Very Less \\
\hline & Total & 48 & 100 & \\
\hline \multicolumn{3}{|c|}{ Average } & 79.09 & Good \\
\hline
\end{tabular}


The employee productivity indicator table shows the largest percentage, namely the predicate of Very Good at $41.67 \%$ with a value of 86-100. While the smallest is $6.25 \%$ with the predicate Very Poor at a value of 55 . With an average value of $79.09 \%$ in the predicate Good.

The distribution of respondents' answers to the independent variable, namely the work environment in this study was measured through respondents' answers to the statements given based on variable indicators. The distribution of respondents' answer data is 48 people. A total of 32 respondents stated that they strongly agreed with a percentage of $67 \%$ on the question of lighting in the workspace to help complete work optimally, while $33 \%$ expressed doubt. As many as $65 \%$ of respondents agreed that they had received sufficient sunlight in the workspace, while $17 \%$ expressed doubt and 9\% strongly disagreed. Furthermore, there were $59 \%$ of respondents stated that the temperature in the workroom was ideal, while only $41 \%$ expressed doubts. Furthermore, $84 \%$ of respondents stated that employees had no difficulty adapting to the air temperature in the workspace, while only $10 \%$ agreed and $6 \%$ expressed doubts.

For the noise level in the workplace, $61 \%$ of respondents stated that it was low enough so that employees were not disturbed in carrying out their duties, while only 39\% expressed doubt and disagreed. Then there are $94 \%$ of respondents stated that noise in the workplace does not interfere with activities and concentration. While only 6\% expressed doubt. Furthermore, $83 \%$ of respondents stated that the air circulation in the workspace allows them to work optimally, while only $17 \%$ stated that they did not hesitate. Based on $90 \%$ of respondents stated that the air quality is quite good because there is the air ventilation, while only $10 \%$ stated strongly agree and hesitate. As many as $63 \%$ of respondents stated that employees can work calmly and optimally because there are security officers, meanwhile, only $37 \%$ expressed doubt.

Then $92 \%$ of respondents stated that parking the vehicle was not a problem because of the high level of security, while only $8 \%$ expressed doubt. Furthermore, $61 \%$ of respondents stated that employees can coordinate with other co-workers, while only $39 \%$ expressed doubt. Based on $85 \%$ of respondents stated that employees have the same goal in completing tasks, while only $15 \%$ expressed doubt.

Furthermore, $79 \%$ of respondents stated that communication between employees went well, while $21 \%$ stated that they strongly agreed and had doubts. Furthermore, $63 \%$ of respondents stated that communication affects relations 
between employees. Meanwhile, only $37 \%$ expressed doubt. Then $94 \%$ of respondents stated that work units within the agency were interdependent in carrying out their duties, while only $6 \%$ stated that they strongly disagreed. Then $91 \%$ of respondents stated that employees are dependent on carrying out their duties, while only $9 \%$ stated that they strongly disagree. Furthermore, 75\% of respondents stated that there was no difference in perception between colleagues in understanding the agency's goals. While only $25 \%$ stated strongly agree.

Based on the respondents' statements, $76 \%$ stated that employees accept differences in perceptions to achieve goals, while only $24 \%$ stated that they disagreed and strongly disagreed. Then $56 \%$ of respondents stated that there was no difference in perception between colleagues in understanding the agency's goals, while only $44 \%$ stated strongly agree. And $98 \%$ of respondents stated that employees compete healthily, while only $2 \%$ stated strongly disagree.

While regarding work productivity, respondents think $96 \%$ have the ability in the field of work they are involved in, while only $4 \%$ express doubts. $94 \%$ of respondents stated that the quality of the work provided was by the ability of the employee, while only $6 \%$ expressed doubt. Furthermore, $58 \%$ of respondents stated that in carrying out their work employees always mean it so that no mistakes occur, while only $42 \%$ expressed doubt. Then $88 \%$ of respondents stated that in doing their work, employees always get the best results, while only $12 \%$ stated that they did not agree.

There are $96 \%$ of respondents stated that employees never complain and feel heavy with the workload that is their responsibility, while only $4 \%$ disagree. In the next statement, $92 \%$ of respondents stated that employees completed their work before the deadline determined by their superiors, while only $8 \%$ said they did not agree. Then $94 \%$ of respondents stated that employees always follow the training held by the agency to improve their skills. While only $6 \%$ stated strongly agree.

Another opinion from respondents, there are $71 \%$ of respondents stated that employees always try to correct mistakes that have been made at work, while $29 \%$ stated strongly agree. Then there are $67 \%$ of respondents stated that employees always try to improve the quality of work. While $33 \%$ stated strongly agree. And $78 \%$ of respondents stated that employees work according to the program, while only $22 \%$ stated that they strongly disagreed. 


\section{Conclusion}

The conclusions that can be drawn from the results of the analysis and discussion of the problems studied in PP-PA South Sumatera Province are that the average work conflict indicator is $81.06 \%$ in a good predicate. The work environment indicator shows an average of $78.76 \%$ in the good predicate. And the employee productivity indicator shows an average of $79.09 \%$ in a good predicate. Of the three elements, there are positive statements from respondents with a percentage of $79.64 \%$ in the predicate Good. This can be interpreted if there is an improvement in the work environment as well as the prevention and handling of work conflicts, a good work environment will increase employee productivity at the PP-PA Office of South Sumatera Province.

\section{Acknowledgement}

We expresses our deepest gratitude to all parties who have provided motivation so that this research can be completed properly, namely the PP-PA Office of South Sumatera Province, Universitas PGRI Palembang, and Universitas Bengkulu.

\section{References}

Darmayanti, Y. (2017). Pengaruh Lingkungan Kerja Dan Standar Operasional Prosedur Terhadap Produktivitas Kerja Karyawan Pengawas Urusan Gerbong Suka Cinta (PUG SCT) PT. Kereta Api Indonesia (PERSERO) Kabupaten Lahat [The Influence of the Work Environment and Standard Operating Procedures on the Work Productivity of the Supervisor for the Suka Cinta Carriage (PUG SCT) PT. Indonesian Railways (PERSERO) Lahat Regency]. Jurnal Pendidikan Ekonomi Dan Bisnis (JEPB), 5(1), 6372. Doi.Org/10.21009/JPEB.005.1.5.

Hamali, AY (2018). Pemahaman Manajemen Sumber Daya Manusia:Strategi Mengelola Karyawan [Understanding Human Resource Management: Strategies for Managing Employees]. Yogyakarta: CAPS (Pusat Layanan Penerbitan Akademik).

Hasibuan, Malayu SP. (2012). Manajemen Sumber Daya Manusia [Human Resource Management]. Revision. Jakarta: Bumi Aksara

Kambey, C., Adolfina, A., \& Sendow, G. (2021). Analisis Konflik Kerja, Komunikasi Kerja, Dan Lingkungan Kerja Terhadap Kinerja Pegawai Di Dinas Pendidikan Daerah Provinsi Sulawesi Utara [Analysis of Work 
Conflict, Work Communication, and Work Environment on Employee Performance at the Regional Education Office of North Sulawesi Province]. Jurnal Emba: Jurnal Riset Ekonomi, Manajemen, Bisnis Dan Akuntansi, 9(3).

Kristanto, A. (2020). Manajemen Konflik [Conflict Management]. Yogyakarta: Gava Media.

Kurbani, A. (2018). Pengaruh Budaya Organisasi Terhadap Kinerja Pegawai Pada Kantor Media Lintas Indonesia Sumatera Selatan [The Influence of Organizational Culture on Employee Performance at the Lintas Indonesia Media Office, South Sumatra]. Jurnal Media Wahana Ekonomika, 15(2), 12-21. Http://Dx.Doi.Org/10.31851/Jmwe.V15i2.2404.

Lestari, ND, \& Toyib, M. (2017). Analisis Laporan Keuangan Bazar Kewirausahaan Produk Kreatif Limbah K5PBB Mahasiswa Program Studi Pendidikan Akuntansi Universitas PGRI Palembang [Financial Statement Analysis of the Creative Product Entrepreneurship Bazaar of K5PBB Waste Students of the Accounting Education Study Program, University of PGRI Palembang]. PROMOSI: Jurnal Program Studi Pendidikan Ekonomi, 5(2).

Masnunah, M., \& Lestari, ND (2020). A Jumputan or Songket Waste Used As a Preventive Mask for Covid 19 in South Sumatra Indonesia. IJEBD International Journal of Entrepreneurship and Business Development eISSN 2597-4785 pISSN 2597-4750, 3(4), 462-469.

Purwanto, M. N. (2017). Prinsip-Prinsip dan Teknik Evaluasi Pengajaran [Teaching Evaluation Principles and Techniques]. Bandung: PT. Remaja Rasdukarya.

Sedarmayanti. (2018). Tata Kerja Dan Produktivitas Kerja: Suatu Tinjauan Dari Aspek Ergonomi Atau Kaitan Antara Manusia Dengan Lingkungan Kerjanya [Work Procedures And Work Productivity: An Overview Of Ergonomics Aspects Or The Relationship Between Humans And Their Work Environment]. Bandung: CV. Mandar Maju.

Sugiyono. (2019). Metode Penelitian Pendidikan Kuantitatif, Kualitatif, R\&D dan Penelitian Pendidikan [Quantitative, Qualitative, R\&D and Educational Research Research Methods]. Bandung: Alfabeta

Sunyoto, D. (2012). Manajemen Sumber Daya Manusia [Human Resource Management]. Yogyakarta: CAPS. 
Sutrisno, E. (2019). Manajemen Sumber Daya Manusia [Human Resource Management]. Jakarta: Prenada Media GROUP.

Syarifudin, I. (2021). Analisis Pengaruh Beban Kerja, Konflik Kerja Dan Lingkungan Kerja Fisik Terhadap Stres Kerja (Studi Pada UD Rahmat Kutowinangun) [Analysis of the Effect of Workload, Work Conflict and Physical Work Environment on Work Stress (Study at UD Rahmat Kutowinangun)]. Dissertasion, Universitas Putra Bangsa.

Widyawati, ED (2020). Analisis Pengaruh Konflik Peran, Lingkungan Kerja Dan Stres Kerja Terhadap Kinerja Karyawan Dengan Budaya Organisasi [Analysis of the Effect of Role Conflict, Work Environment and Work Stress on Employee Performance with Organizational Culture]

Wardhana, E., Lengkong, VP, \& Taroreh, RN (2019). Analisis Lingkungan Kerja, Konflik Kerja, Komunikasi Kinerja Karyawan Di TVRI Manado [Work Environment Analysis, Work Conflict, Employee Performance Communication at TVRI Manado]. Jurnal EMBA: Jurnal Riset Ekonomi, Manajemen, Bisnis Dan Akuntansi, 7(1).

Yusuf, B. (2015). Manajemen Sumber Daya Manusia: Di Lembaga Keuangan Syariah [Human Resource Management: In Islamic Financial Institutions]. Jakarta: Rajagrafindo Persada 